\title{
Pengaruh Pendapatan Asli Daerah, Belanja Modal dan Indeks Pembangunan Manusia
}

\author{
Yustina Asnad Hobrouw ${ }^{1}$ \\ Fakultas Ekonomi dan Bisnis \\ Universitas Udayana, Indonesia
}

\author{
I Gusti Ngurah Agung Suaryana ${ }^{2}$ \\ Fakultas Ekonomi danBisnis \\ Universitas Udayana, Indonesia
}

\author{
I G.A.M. Asri Dwija Putri ${ }^{3}$ \\ Fakultas Ekonomi dan Bisnis \\ Universitas Udayana, Indonesia
}

\begin{abstract}
Surel : yustin_asnad@yahoo.com
ABSTRAK

Penelitian ini bertujuan untuk mengetahui secara empiris Pengaruh pendapatan Asli Daerah pada Peningkatan Indeks Pembangunan Manusia di Provinsi Papua Barat dan untuk mengetahui secara empiris pengaruh Belanja Modal pada Peningkatan Indeks Pembangunan Manusia di Provinsi Papua Barat. Teknik analisis data yang digunakan adalah analisis regresi linear berganda. Berdasarkan hasil analisis, diketahui bahwa Pendapatan Asli Daerah berpengaruh positif dan signifikan pada peningkatan Indeks Pembangunan Manusia Kabupaten/Kota di Provinsi Papua Barat. Hal ini menunjukkan bahwa meningkatnya Pendapatan Asli Daerah (PAD) maka cenderung akan meningkatkan Indeks Pembangunan Manusia. Belanja Modal berpengaruh positif dan signifikan pada peningkatan Indeks Pembangunan Manusia Kabupaten/Kota di Provinsi Papua Barat.
\end{abstract}

Kata Kunci: PAD; Belanja Modal; Indeks Pembangunan Manusia.

\section{The Influence of Local Own Income, Capital Expenditures and Human Development Index}

\begin{abstract}
This study aims to determine empirically the effect of local revenue on the increase in the human development index in West Papua province and to empirically determine the effect of capital expenditure on the increase in the human development index in West Papua province. The data analysis technique used is multiple linear regression analysis. Based on the results of the analysis, it is known that the Original Regional Income has a positive and significant effect on the increase in the District / City Human Development Index in West Papua Province. This shows that an increase in Regional Original Income (PAD) will tend to increase the Human Development Index. Capital expenditure has a positive and significant effect on increasing the District / City Human Development Index in West Papua Province.
\end{abstract}

Keywords: PAD; Capital Expenditures; Human Development Index.

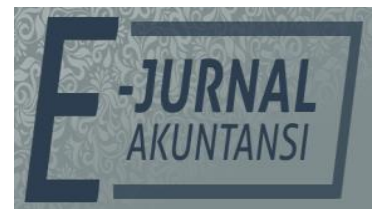

e-ISSN 2302-8556

Vol. 31 No. 2

Denpasar, Februari 2021

Hal. 401-413

DOI:

10.24843/EJA.2021.v31.i02.p11

PENGUTIPAN:

Hobrouw, Y.A., Suaryana, I

G.N.A., \& Putri, I G.A.M.

(2021). Pengaruh

Pendapatan Asli Daerah,

Belanja Modal dan Indeks

Pembangunan Manusia. EJurnal Akuntansi, 31(2), 401-

413

RIWAYAT ARTIKEL:

Artikel Masuk:

20 Agustus 2020

Artikel Diterima:

8 Februari 2021

Artikel dapat diakses : https://ojs.unud.ac.id/index.php/Akuntansi/index 


\section{PENDAHULUAN}

Anggaran Pendapatan dan Belanja Daerah (APBD) belum dapat dimanfaatkan secara optimal untuk kesejahteraan masyarakat. Hal ini di tunjukkan dengan belanja daerah yang seharusnya ditujukan untuk kepentingan publik, namun pada kenyataan nya terdapat beberapa Kabupaten/Kota di Provinsi Papua Barat yang mengalokasikan belanja daerah pada pos-pos yang kurang tepat sehingga tidak sesuai dengan kepentingan dan kebutuhan masyarakat. López et al. (2010) Peran pemerintah dalam mengelola pendapatan suatu daerah dapat mempercepat pertumbuhan ekonomi dan mengurangi kemiskinan yang besar.

Hal tersebut sesuai dengan teori keagenan (agency theory) yang mengatakan bahwa antara agen dan principalnya tidak selalu memiliki kepentingan yang sama seperti adanya benturan kepentingan masyarakat (principal) dengan pemerintah daerah (agen) tentunya dapat menyebabkan belanja daerah kurang maksimal dirasakan manfaatnya (Soejoto et al., 2015). Priambodo \& Noor (2015) menjelaskan bahwa pemerintah menggunakan APBD untuk membiayai pembangunan di sektor-sektor terkait pembangunan manusia. Spesifiknya, pemerintah daerah harus dapat mengalokasikan belanja daerah melalui pengeluaran pembangunan di sektor-sektor pendukung untuk meningkatkan IPM, pada bidang pendidikan, bidang kesehatan, dan bidang infrastruktur (Ehimare et al., 2014).

Pendapatan Asli Daerah atau yang disingkat PAD adalah pendapatan yang diperoleh daerah yang dipunggut berdasarkan peraturan sesuai dengan peraturan perundang-undangan yang dalam hal ini adalah UU No 33 Tahun 2004. Pendapatan Asli Daerah bersumber dari pajak daerah, retribusi daerah, hasil pengelolaan kekayaan daerah yang dipisahkan dan lain-lain pendapatan daerah yang sah. Pendapatan Asli Daerah bertujuan memberikan kewenangan kepada pemerintah daerah untuk mendanai pelaksanaan otonomi daerah sesuai dengan potensi daerah sebagai perwujudan desentralisasi. Merujuk pada Undang-undang Nomor 33 Tahun 2004 Pasal 1 Ayat 18 menyebutkan pendapatan asli daerah, selanjutnya disebut PAD adalah pendapatan yang diperoleh daerah yang dipungut berdasarkan peraturan daerah sesuai dengan peraturanperundang-undangan.

Penelitian yang dilakukan oleh Holtz-Eakin et al. (1985) menunjukkan adanya keterkaitan yang sangat erat antara transfer pemerintah pusat dengan belanja pemerintah daerah. Berbagai kebijakan pemerintah daerah dalam jangka pendek ditentukan oleh transfer yang diterima oleh pemerintah pusat. Naganathan \& Sivagnanam (2000), menjelaskan bahwa alokasi dan transfer dinegara-negara sedang berkembang seperti Indonesia pada umumnya lebih didasarkan pada aspek pengeluaran pemerintah daerah dan kurangnya memperhatikan kemampuan pengumpulan potensi keunggulan lokal. Tingginya ketergantungan keuangan daerah terhadap pusat, sekaligus menjadi tekanan dalam pengumpulan PAD di Provinsi. Padahal jika pemerintah daerah dapat memanfaatkan potensi yang dimiliki oleh daerahnya sendiri, tentu ini akan menjadi suatu hal yang sangat menguntungkan karena pengelolaan daerah dapat menciptakan lapangan kerja baru bagi masyarakat yang dapat merangsang perkembangan dan pertumbuhan ekonomi sehingga pendapatan bagi daerah juga mengalami peningkatan. 
IPM dapat digunakan sebagai alat ukur keberhasilan pembangunan di suatu daerah dan salah satu petunjuk untuk melihat apakah pembangunan yang telah dilakukan sesuai dengan yang ditetapkan. Sumber dana yang dibutuhkan untuk pembangunan daerah bersumber dari Pendapatan Asli Daerah.Semakin mandiri suatu daerah berarti Pendapatan Asli Daerah mampu membiayai pembangunan daerahnya. Data berkaitan dengan Pendapatan Asli Daerah Kabupaten/Kota di Provinsi Papua Barat disajikan pada Tabel 1, berikut.

Tabel 1. Pendapatan Asli Daerah Kabupaten/Kota di Provinsi Papua Barat

\begin{tabular}{llllll}
\hline \multicolumn{1}{c}{ Kabupaten } & & \multicolumn{2}{c}{ Pendapatan } & Asli Daerah (dalam rupiah ) & \\
\cline { 3 - 5 } & \multicolumn{1}{c}{2014} & \multicolumn{1}{c}{2015} & \multicolumn{1}{c}{2016} & 2017 & \multicolumn{1}{c}{2018} \\
\hline Fakfak & 37929106 & 76400161 & 97943095 & 61396069 & 64306621 \\
Kaimana & 16535688 & 16298318 & 15401944 & 30909417 & 24367296 \\
Teluk Wondama & 7500000 & 7500000 & 7732284 & 16207000 & 18021200 \\
Teluk Bintuni & 32325000 & 37388312 & 40000000 & 50000000 & 55000000 \\
Manokwari & 42408000 & 61396676 & 59664661 & 60976919 & 58658566 \\
Sorong Selatan & 19992779 & 17911680 & 17500000 & 17598000 & 21159978 \\
Sorong & 51039887 & 68882500 & 143422702 & 74353856 & 166056942 \\
Raja Ampat & 23882211 & 23900000 & 50000000 & 65000000 & 58455119 \\
Tambrauw & 5465672 & 4261672 & 34629098 & 5884494 & 2252768 \\
Maybrat & 4500000 & 1700000 & 10550000 & 3929000 & 2150864 \\
Manokwari Selatan 0 & 2428198 & 4559050 & 4092039 & 3475000 \\
Pegunungan Arfak 19999 & 282000 & 5147091 & 2824214 & 4403109 \\
Kota Sorong & 51039887 & 80796486 & 106934335 & 171785882 & 166056942 \\
Papua Barat & 329403192 & 11457329261 & 593484260 & 13329057544 & 555387612 \\
\hline
\end{tabular}

Sumber: Biro Keuangan Setda Propinsi Papua Barat, 2019

Berdasarkan Tabel 1, PAD terendah secara keseluruhan di Provinsi Papua Barat di peroleh Kabupaten Pegunungan Arfak yaitu 19 999, sedangkan PAD tertinggi adalah Kota Sorong 171785882 pada tahun 2017 dan pada posisi kedua PAD tertinggi adalah Kota Sorong yaitu 166056942 pada tahun 2018. Apabila dibandingkan dengan rata-rata Peningkatan IPM Kabupaten/Kota di Provinsi Papua Barat, justru Kota Sorong dan Kabupaten Sorong berada pada tingkat terbawah. Hal ini mengindifikasikan bahwa PAD yang diperoleh Kabupaten Sorong dan Kota Sorong diduga tidak sepenuhnya digunakan untuk menaikkan sektor-sektor yang dapat meningkatkan IPM. PAD di seluruh Provinsi Papua Barat terus meningkat setiap tahunnya semestinya dibarengi dengan peningkatan IPM karena daerah mengalokasikan belanja daerahnya untuk menaikan sektor-sektor yang mendorong peningkatan IPM. Strategi alokasi belanja daerah menaikkan peranan yang tidak kalah penting guna meningkatkan Indeks Pembangunan Manusia.

Belanja Daerah menurut Standar Akuntansi Pemerintahan (SAP) terdiri dari Belanja Modal dan Belanja Rutin. Belanja Modal yang dilakukan oleh pemerintah daerah terdiri atas Belanja Aset Tetap dan Belanja Aset Lainnya, seperti pembangunan dan perbaikan sektor pendidikan, kesehatan, transportasi, sehingga masyarakat juga menikmati manfaat dari pembangunan daerah. Anggaran Belanja Modal didasarkan pada kebutuhan daerah akan sarana, dan prasarana, baik untuk kelancaran pelaksanaan tugas pemerintahan maupun untuk fasilitas publik. Modebe (2012) menjelaskan bahwa dengan adanya inftraskturtur yang baik akan dapat meningkatkan produktivitas. Meningkatnya 
pengeluaran modal diharapkan dapat meningkatkan pelayanan publik karena hasil dari pengeluaran belanja modal dapat meningkatkan aset tetap daerah yang merupakan prasyarat dalam memberikan pelayanan publik oleh pemerintah daerah.

Upaya peningkatan kualitas pelayanan publik mengharuskan pemerintah daerah mengubah komposisi belanjanya. Belanja modal dilakukan oleh pemerintah dalam pengadaan aset daerah sebagai investasi, pada akhirnya mampu meningkatkan kesejahteraan masyarakat karena adanya peningkatan pelayanan pada sektor publik (Hukom, 2015). Data berkaitan dengan Belanja Modal Kabupaten/Kota di Provinsi Papua Barat disajikan pada Tabel 2, berikut

Tabel 2. Belanja Modal Kabupaten/ Kota di Provinsi Papua Barat

\begin{tabular}{llllll}
\hline Kabupaten & \multicolumn{5}{c}{ Belanja modal (dalam rupiah) } \\
\cline { 2 - 5 } & 2014 & 2015 & 2016 & 2017 & 2018 \\
\hline Fakfak & 343771248 & 313189993 & 313189993 & 297579976 & 341206641 \\
Kaimana & 258714106 & 295750431 & 295750431 & 298109771 & 262879855 \\
Teluk Wondama & 199537409 & 192759626 & 197706576 & 129256984 & 207371370 \\
Teluk Bintuni & 548450544 & 844907340 & 915088032 & 823963855 & 862523986 \\
Manokwari & 153464248 & 193176226 & 272250114 & 324779105 & 261228621 \\
Sorong Selatan & 222705929 & 191067924 & 276897779 & 194881380 & 238529897 \\
Sorong & 324649249 & 365130649 & 385301395 & 221799063 & 371327374 \\
Raja Ampat & 362996176 & 316563936 & 437369539 & 313427093 & 240044064 \\
Tambrauw & 239179893 & 329380579 & 371609311 & 203929469 & 593112900 \\
Maybrat & 234974258 & 254134518 & 305578596 & 258521722 & 227477177 \\
Manokwari & 34680786 & 288942857 & 315369652 & 155339998 & 174574989 \\
Selatan & & & & & \\
Pegunungan & 44076716 & 260398390 & 276285325 & 174610316 & 220447655 \\
Arfak & & & & & \\
Kota Sorong & 203040020 & 169572849 & 255503797 & 240813534 & 252145991 \\
Papua Barat & 3118363181 & 4014975418 & 4709770524 & 3646012266 & 4252470520 \\
\hline
\end{tabular}

Sumber: Biro Keuangan Setda Propinsi Papua Barat, 2019

Berdasarkan Tabel 2, menunjukkan Belanja Modal tertinggi adalah Kabupaten Teluk Bintuni, sedangkan yang terendah adalah Kabupaten Teluk Wondama, Pengalokasian Belanja Modal ini sesuai dengan Pendapatan Asli Daerah yang diperoleh masing-masing daerah dimana PAD tertinggi yaitu Kota Sorong, terendah yaitu Kabupaten Pegunungan Arfak.Pengalokasian belanja modal ini dianggarkan sesuai dengan kebutuhan di daerah.

Upaya peningkatan IPM tidak terlepas dari peran pemerintah dalam mengalokasikan sumber-sumber pendapatan daerah pada belanja daerah untuk sektor-sektor yang dapat menaikkan IPM seperti bidang pendidikan, kesehatan, dan infrastruktur. Sesuai dengan UU Nomor 32 Tahun 2004 tentang Pemerintah Daerah, yaitu adanya pelimpahan wewenang dari pemerintah pusat kepada daerah otonom untuk mengatur dan mengurus sendiri urusan pemerintahan. Otonomi daerah memungkinkan percepatan pembangunan, karena daerah diberi wewenang dalam menyelesaikan permasalahan daerah (Sari \& Supadmi, 2016). Pemerintah daerah diharapkan dapat mengelola sumber daya yang dimilikinya dan melaksanakan tata kelola pemerintahan yang baik sehingga 
akan berdampak pada pelayanan yang diberikan kepada masyarakat (Handra \& Maryati, 2009).

Provinsi Papua Barat sebagai salah satu daerah otonom di Indonesia turut merasakan dampak dari diberlakukannya otonomi daerah khususnya dalam penyusunan Anggaran Pendapatan dan Belanja Daerah (APBD). APBD tersusun atas komponen penerimaan daerah dan belanja daerah, dana perimbangan dan lain-lain pendapatan daerah yang sah. Sedangkan pengeluaran dilakukan oleh daerah dalam bentuk belanja daerah (Vegirawati, 2012). APBD disusun oleh pemerintah suatu daerah untuk meningkatkan pendapatan daerah dan kesejahteraan masyarakatnya karena dengan adanya APBD, suatu daerah dapat memaksimalkan sumber-sumber pendapatan daerah, membelanjakan dana tersebut sesuai program dan kegiatan yang telah direncanakan dan ditetapkan dalam peraturan daerah setempat, namun proses penyusunan APBD tidak selamanya berjalanan baik.

Penyusunan APBD seringkali berbenturan dengan kepentingan politis dan birokrasi pemerintahan. Teori Pilihan Rasional menyatakan bahwa teori ini mencoba menjembatani antara ekonomi mikro dan politik dengan melihat pada tindakan warga, politisi, dan pelayanan publik serta melihat bagaimana bagaimana pilihan tindakan yang dilakukan pemerintah daerah dalam perumusan kebijakan publik seperti penyusunan APBD. Pemanfaatan belanja hendaknya dialokasikan untuk hal produktif, misalnya melakukan aktivitas pembangunan melalui belanja modal dalam rangka pembentukan modal yang sifatnya menambah inventaris yang memberikan manfaat lebih dari satu periode akuntansi termasuk di dalamnya adalah pengeluaran untuk biaya pemeliharaan yang sifatnya mempertahankan atau menambah manfaat dan meningkatkan kapasitas serta kualitas aset (Haryanto, 2013).

Sari \& Supadmi (2016) melakukan penelitian dengan judul Pengaruh Pendapatan Asli Daerah dan Belanja Modal terhadap Indeks Pembangunan Manusia pada Kabupaten/Kota di Provinsi Bali. Hasil penelitiannya menunjukkan Pendapatan Asli Daerah memiliki pengaruh positif dan signifikan pada Peningkatan IPM Kabupaten/Kota di Provinsi Bali. Hal ini berarti, semakin meningkat Pendapatan Asli Daerah, maka peningkatan Indeks Pembangunan Manusia juga meningkat. Belanja modal berpengaruh positif dan signifikan pada Peningkatan IPM Kabupaten/Kota Provinsi Bali. Hal ini berarti, semakin meningkat belanja modal, maka peningkatan Indeks Pembangunan Manusia jugameningkat.

Penelitian Yanto \& Fattah (2018) yang mengungkapkan bahwa Pendapatan Asli Daerah (PAD) dan Belanja Modal secara simultan dan signifikan berpengaruh terhadap variabel Indeks Pembangunan Manusia (IPM). Hasil Penelitian ini berbeda dengan penelitian yang dilakukan Kresnandra (2016) dan Azzahra et al. (2016) bahwa belanja modal tidak berpengaruh terhadapIPM. Menurut Sasana (2012), belanja langsung diperuntukkan guna meningkatkan kualitas sarana dan prasarana umum atau program-program langsung yang dapat merangsang peningkatan produktivitas masyarakat serta pelaku usaha di daerah.

Badrudin (2011) mengatakan IPM yang tinggi belum tentu merupakan kontribusi penuh dari alokasi belanja yang dilakukan oleh pemerintah daerah. 
Tidak semua daerah dengan PAD dan jumlah belanja daerah yang tinggi memiliki IPM yang tinggi pula. Pencapaian tingkat kesejahteraan tersebut dapat dilakukan secara mandiri oleh masyarakat dan sangat dipengaruhi oleh kondisi dan kekuatan ekonomi, sosial, dan budaya masyarakat itu sendiri. Namun, apabila sumber PAD dan pengalokasian belanja modal dilakukan secara tepat akan berdampak pada peningkatan kesejahteraan masyarakat yang dapat diukur melalui Indeks Pembangunan Manusia.

Pendapatan Asli daerah digunakan oleh pemerintah daerah di dalam membiayai belanja daerahnya (Situngkir, 2009). Ashworth et al. (2005) menyatakan bahwa tingkat pendapatan akan memiliki pengaruh positif pada pengeluaran publik. Tingkat kemandirian suatu daerah terlihat dari kemampuan PAD dalam membiayai pembangunan daerahnya. Jika suatu daerah semakin mandiri berarti pendapatan asli daerah tersebut akan semakin mampu membiayai pembangunan daerahnya sendiri. Tujuan utama pembangunan daerah selain kemandirian fiscal adalah untuk meningkatkan kesejahteraan masyarakat menjadi lebih baik melalui pembangunan manusia yang diukur melalui IPM (Pamudi, 2008).

PAD memiliki peran yang sangat penting terhadap peningkatan IPM, dengan kata lain PAD berpengaruh terhadap peningkatan Indeks Pembangunan Manusia.Peningkatan PAD yang diterima pemerintah daerah berarti daerah memliki cukup dana untuk belanja daerah pada sektor-sektor yang mendukung IPM seperti bidang kesehatan, pendidikan, dan infrastruktur. Hal ini didukung oleh hasil penelitian Setyowati \& Suparwati (2012), Lugastoro (2013) dan Sari \& Supadmi (2016) yang mengatakan bahwa PAD berpengaruh positif terhadap Indeks Pembangunan Manusia. Berdasarkan hasil penelitian tersebut, hipotesis yang dirumuskan dalam penelitian ini sebagai berikut.

$\mathrm{H}_{1}$ : Pendapatan Asli Daerah berpengaruh positif dan signifikan pada Indeks Pembangunan Manusia Kabupaten/Kota di Provinsi Papua Barat.

Berdasarkan teori fiscal federalism, faktor penting dari desentralisasi fiscal adalah pemerintah Kabupaten/Kota diberi otonomi untuk menentukan alokasi realisasi mereka. Alokasi belanja modal pemerintah Kabupaten/Kota termasuk dalam desentralisasi fiscal (Pradana, 2018). Belanja modal digunakan oleh pemerintah Kabupaten/Kota untuk perolehan aset tetap dan aset lainnya yang memberi manfaat lebih dari satu tahun anggaran. Belanja modal urusan pendidikan terkait dengan IPM. Diterimanya penerimaan yang bersumber dari pengelolaan sumber daya daerah seperti PAD dan juga bantuan dari pemerintah pusat yang berupa DAU dan DAK, maka alokasi dana untuk meningkatkan kesejahteraan masyarakat seharusnya juga semakin baik. Christy \& Adi (2009) mengatakan untuk meningkatkan kemajuan daerah dan mensejahterakan masyarakat daerah diperlukan pengalokasian dan belanja modal yang lebih besar berupa pembangunan gedung, sarana dan prasarana yangmemadai.

Peningkatan sarana dan prasarana publik serta investasi pemerintah yang meliputi perbaikan fasilitas pendidikan, kesehatan, dan sarana penunjang lainnya akan meningkatkan pelayanan sektor publik secara berkelanjutan (Bati, 2009). Hal tersebut akan berdampak pada peningkatan kesejahteraan masyarakat. 
Belanja Modal dialokasikan berdasarkan kebutuhan daerah akan sarana dan prasarana daerah, disamping itu juga mendapatkan aset tetap daerah (Solikin, 2007). Belanja modal dilakukan oleh Pemda (Pemerintah Daerah) dalam pengadaan aset daerah sebagai investasi, pada akhirnya mampu untuk meningkatkan sarana dan prasarana publik sehingga menunjang peningkatan pelayanan sektor publik. Belanja modal memiliki peran yang penting terhadap peningkatan indeks pembangunan manusia. Hal ini didukung oleh hasil penelitian (Setyowati \& Suparwati (2012), Sari \& Supadmi (2016), Yanto \& Fattah (2018) mengatakan alokasi belanja modal berpengaruh positif terhadap indeks pembangunan manusia. Berdasarkan hal tersebut, maka hipotesis yang dapat dirumuskan sebagaiberikut.

$\mathrm{H}_{2}$ : Belanja Modal berpengaruh positif dan signifikan pada Indeks Pembangunan Manusia (IPM) Kabupaten/Kota Provinsi Papua Barat.

\section{METODE PENELITIAN}

Penelitian dilakukan di Biro Keuangan Provinsi Papua Barat dan Badan Pusat Statistik Provinsi Papua Barat. Sementara ruang lingkup dari penelitian adalah Kabupaten/Kota se- Provinsi Papua Barat. Populasi dalam penelitian ini adalah seluruh laporan realisasi APBD Kabupaten/Kota di Provinsi Papua Barat tahun 2014-2018. Sampel yang digunakan dalam penelitian ini adalah laporan realisasi APBD Kabupaten/Kota di Provinsi Papua Barat tahun 2014-2018 yang terdiri dari 12 Kabupaten dan 1 Kota dengan kurun waktu 5 tahun (2014-2018) jadi jumlah sampel dalam penelitian ini adalah sebanyak 65 amatan.

Pengumpulan data dapat diperoleh dari sumber data yang digunakan dengan cara melakukan pencatatan informasi yang terjadi terhadap data sekunder yang berupa laporan realisasi APBD Kabupaten/Kota di Provinsi Papua Barat yang diperoleh dari Biro Keuangan Provinsi Papua Barat serta www.djpk.kemenkeu.go.id dan indeks pembangunan manusia tahun 2014-2018 yang diperoleh dari Badan Pusat Statistik Provinsi Papua Barat serta hasil-hasil penelitian dalam jurnal dan buku-buku literatur untuk menghasilkan argumentasi yang mendukung hasil analisis penelitian.

Teknik analisis data yang digunakan dalam penelitian ini adalah analisis regresi linear berganda dengan menggunakan program Statistical Package for Social Science (SPSS). Persamaan regresi linear berganda dalam penelitian ini yaitu sebagai berikut.

$\mathrm{Y}=\mathrm{a}+\beta_{1} \mathrm{X}_{1}+\beta_{2} \mathrm{X}_{2}+\varepsilon$

Keterangan:

$\mathrm{Y} \quad=$ Indeks pembangunan manusia

a $\quad=$ Konstanta

$\beta_{1} \beta_{2}=$ Koefisien regresi

$\mathrm{X}_{1}=$ Pendapatan Asli Daerah

$\mathrm{X}_{2} \quad=$ Belanja modal

$\varepsilon=$ Standard error 
HASIL DAN PEMBAHASAN

Analisis statistik deskriptif memberikan gambaran atau deskripsi suatu data yang dapat dilihat dari besarnya nilai minimum, mean, dan simpangan baku (standard deviation) dengan $\mathrm{N}$ merupakan banyaknya responden penelitian. Hasil analisis statistik deskriptif dapat dilihat dalam Tabel 3.

Tabel 3. Statistik Deskriptif

\begin{tabular}{llllll}
\hline & $\mathrm{N}$ & Minimum & Maximum & Mean & Std. Deviation \\
\hline IPM & 65 & 49,40 & 77,35 & 61,2262 & 6,65766 \\
PAD & 65 & 9,90 & 18,96 & 16,6765 & 1,61312 \\
Belanja Modal & 65 & 17,36 & 20,63 & 19,3993 & 0,53031 \\
\hline
\end{tabular}

Sumber: Data Penelitian, 2020

Statistik deskriptif pada Tabel 3, menunjukkan bahwa nilai minimum dan maksimum variabel IPM (Y) sebesar 49,40 dan 77,35. Rata-ratanya (mean) sebesar 61,2262 dengan standar deviasi sebesar 6,65766, hal ini berarti bahwa terjadi perbedaan nilai IPM yang diteliti terhadap nilai rata-ratannya sebesar 6,65766. Nilai minimum dan maksimum variabel PAD (X1) sebesar 9,90 dan 18,96. Rataratanya (mean) sebesar 16,6765 dengan standar deviasi sebesar 1,61312, hal ini berarti bahwa terjadi perbedaan nilai PAD yang diteliti terhadap nilai rataratannya sebesar 1,61312. Nilai minimum dan maksimum variabel belanja modal (X2) sebesar 17,36 dan 20,63. Rata-ratanya (mean) sebesar 19,3993 dengan standar deviasi sebesar 0,53031, hal ini berarti bahwa terjadi perbedaan nilai perputaran persediaan yang diteliti terhadap nilai rata-ratannya sebesar 0,53031.

Analisis regresi linear berganda digunakan untuk mengetahui ketergantungan satu variabel terikat hanya pada satu variabel bebas dengan atau tanpa variabel moderator, serta untuk mengetahui ketergantungan satu variabel terikat pada variabel-variabel bebas. Uji ini dilakukan untuk mengetahui besarnya pengaruh PAD (X1) dan belanja modal (X2) terhadap Indeks Pembangunan Manusia (Y). Hasil uji regresi linear berganda dapat dilihat pada Tabel 4.

Tabel 4. Hasil Analisis Regresi Linear Berganda

\begin{tabular}{llllll}
\hline \multirow{2}{*}{ Model } & \multicolumn{2}{l}{ Unstandardized Coefficients } & $\begin{array}{l}\text { Standardized } \\
\text { Coefficients }\end{array}$ & $\mathrm{t}$ & \multirow{2}{*}{ Sig. } \\
\cline { 2 - 4 } & $\mathrm{B}$ & Std. Error & Beta & & \\
\hline (Constant) & 1,025 & 0,355 & & 2,887 & 0,015 \\
PAD & 0,050 & 0,014 & 0,401 & 3,571 & 0,001 \\
Belanja Modal & 0,041 & 0,013 & 0,301 & 3,154 & 0,009 \\
Adjusted R Square & 0,241 & & & & \\
F Statistik Signifikansi & 6,235 & & & & \\
& 0,003 & & & & \\
\hline
\end{tabular}

Sumber: Data Penelitian, 2020

Berdasarkan hasil analisis regresi linier berganda seperti yang disajikan pada Tabel 4, maka persamaan regresinya adalah sebagai berikut.

$$
\mathrm{Y}=1,025+0,050 \mathrm{X} 1+0,041 \mathrm{X} 2
$$

Hasil Uji Anova atau (F test) pada Tabel 4 menunjukan nilai $\mathrm{F}$ hitung sebesar 6,235 dengan signifikansi 0,003 yang probabilitas signifikan lebih kecil dari alpha 0,05. Ini menunjukan model yang digunakan pada penelitian ini adalah layak. PAD dan belanja modal dapat digunakan untuk memprediksi Indeks Pembangunan Manusia atau dapat dikatakan bahwa PAD dan belanja 
modal secara bersama-sama berpengaruh terhadap Indeks Pembangunan Manusia.

Analisis koefisien determinasi dilakukan untuk mengukur seberapa besar variabel bebas mampu menjelaskan perubahan variabel terikatnya. Pada penelitian ini koefisien determinasi dilihat melalui nilai Adjust $R$ Square. Berdasarkan Tabel 4, Adjusted $R$ Square sebesar 0,241 mempunyai arti bahwa sebesar 24,1 persen variasi Indeks Pembangunan Manusia dipengaruhi oleh variasi PAD dan belanja modal, sedangkan sisanya sebesar 75,9 persen djelaskan oleh faktor lain yang tidak dimasukkan ke dalam model.

Tabel 5. Hasil Analisis Uji Statistik t

\begin{tabular}{lllll}
\hline Variabel & $\begin{array}{l}\text { Koefisien } \\
\text { Regresi }\end{array}$ & t hitung & Sig & Hasil Hipotesis \\
\hline PAD $(\mathrm{X} 1)$ & 0,050 & 3,571 & 0,001 & H1 diterima \\
Belanja Modal & 0,041 & 3,154 & 0,009 & H2 diterima \\
$(\mathrm{X} 2)$ & & &
\end{tabular}

Sumber: Data Penelitian, 2020

Berdasarkan dari hasil pengujian yang ditunjukan Tabel 5, diketahui bahwa tingkat signifikan $\mathrm{t}$ sebesar 0,001 yang berarti lebih kecil atau dibawah nilai $a=0,05$. Hal ini menunjukan bahwa PAD berpengaruh positif dan signifikan terhadap Indeks Pembangunan Manusia. Hal ini berarti adanya pengaruh antara PAD dengan Indeks Pembangunan Manusia, dimana ketika PAD meningkat maka Indeks Pembangunan Manusia juga akan meningkat.

PAD merupakan salah satu sumber pendapatan daerah untuk membiayai segala belanja daerah. PAD berasal dari pajak daerah yang dibayar oleh pihak wajib pajak di daerah tersebut, retribusi daerah, BUMD, dan lain-lain pendapatan yang sah. Kemampuan suatu daerah dalam menyediakan pendanaan yang bersumber dari daerah sangat ditentukan padakemampuan daerah dalam menyediakan pendanaan yang bersumber dari daerah sangat ditentukan pada kemampuan daerah tersebut dalam merealisasikan potensi ekonomi daerah tersebut menjadi bentuk-bentuk kegiatan ekonomi yang mampu menciptakan perguliran dana untuk pembangunan daerah yang berkelanjutan (Darwanto \& Yustikasari, 2007).

Pembangunan suatu daerah yang dilakukan secara otonom harus disertai dengan penguatan penerimaan fiscal daerah sebagai landasan pelaksanaan pembangunan. Hal ini menuntut setiap daerah agar dapat mengoptimalkan pendapatan asli daerah sebagai sumber penerimaan dan pembiayaan daerah (Pamudi, 2008). PAD merupakan sumber yang penting dalam penyelenggaraan ekonomi daerah. Hal ini berarti besar kecilnya PAD dapat meningkatkan atau mengurangi ketergantungan pada pemerintah pusat (Setyowati \& Suparwati, 2012).

Pendapatan Asli daerah digunakan oleh pemerintah daerah di dalam membiayai belanja daerahnya (Situngkir, 2009). Ashworth et al. (2005) menyatakan bahwa tingkat pendapatan akan memiliki pengaruh positif pada pengeluaran publik. Tingkat kemandirian suatu daerah terlihat dari kemampuan PAD dalam membiayai pembangunan daerahnya. Jika suatu daerah semakin mandiri berarti pendapatan asli daerah tersebut akan semakin mampu membiayai pembangunan daerahnya sendiri. Tujuan utama pembangunan 
daerah selain kemandirian fiscal adalah untuk meningkatkan kesejahteraan masyarakat menjadi lebih baik melalui pembangunan manusia yang diukur melalui IPM (Pamudi, 2008).

PAD memiliki peran yang sangat penting terhadap peningkatan IPM, dengan kata lain PAD berpengaruh terhadap peningkatan Indeks Pembangunan Manusia. Peningkatan PAD yang diterima pemerintah daerah berarti daerah memliki cukup dana untuk belanja daerah pada sektor-sektor yang mendukung IPM seperti bidang kesehatan, pendidikan, dan infrastruktur. Hal ini didukung oleh hasil penelitian Setyowati \& Suparwati (2012), Lugastoro (2013) dan Sari \& Supadmi (2016) yang mengatakan bahwa PAD berpengaruh positif terhadap Indeks Pembangunan Manusia.

Berdasarkan dari hasil pengujian yang ditunjukan Tabel 5, diketahui bahwa tingkat signifikan $t$ sebesar 0,009 yang berarti lebih kecil atau dibawah nilai $a=0,05$. Hal ini menunjukan bahwa belanja modal berpengaruh positif dan signifikan terhadap Indeks Pembangunan Manusia. Hal ini berarti adanya pengaruh antara belanja modal dengan Indeks Pembangunan Manusia, dimana ketika belanja modal meningkat maka Indeks Pembangunan Manusia juga akan meningkat.

Hasil penelitian ini sesuai dengan teori fiscal federalism, dimana faktor penting dari desentralisasi fiscal adalah pemerintah Kabupaten/Kota diberi otonomi untuk menentukan alokasi realisasi mereka. Alokasi belanja modal pemerintah Kabupaten/Kota termasuk dalam desentralisasi fiscal (Pradana, 2018). Belanja modal digunakan oleh pemerintah Kabupaten/Kota untuk perolehan aset tetap dan aset lainnya yang memberi manfaat lebih dari satu tahun anggaran. Belanja modal urusan pendidikan terkait dengan IPM. Diterimanya penerimaan yang bersumber dari pengelolaan sumber daya daerah seperti PAD dan juga bantuan dari pemerintah pusat yang berupa DAU dan DAK, maka alokasi dana untuk meningkatkan kesejahteraan masyarakat seharusnya juga semakin baik. Christy \& Adi (2009) berpendapat bahwa untuk meningkatkan kemajuan daerah dan mensejahterakan masyarakat daerah diperlukan pengalokasian dan belanja modal yang lebih besar berupa pembangunan gedung, sarana dan prasarana yang memadai. Peningkatan sarana dan prasarana publik serta investasi pemerintah yang meliputi perbaikan fasilitas pendidikan, kesehatan, dan sarana penunjang lainnya akan meningkatkan pelayanan sektor publik secara berkelanjutan (Bati, 2009). Hal tersebut akan berdampak pada peningkatan kesejahteraanmasyarakat.

Belanja Modal dialokasikan berdasarkan kebutuhan daerah akan sarana dan prasarana daerah, disamping itu juga mendapatkan aset tetap daerah (Solikin, 2007). Belanja modal dilakukan oleh Pemda (Pemerintah Daerah) dalam pengadaan aset daerah sebagai investasi, pada akhirnya mampu untuk meningkatkan sarana dan prasarana publik sehingga menunjang peningkatan pelayanan sektor publik. Belanja modal memiliki peran yang penting terhadap peningkatan indeks pembangunan manusia. Hal ini didukung oleh hasil penelitian dari Setyowati \& Suparwati (2012), Sari \& Supadmi (2016), Yanto \& Fattah (2018) mengatakan alokasi belanja modal berpengaruh positif terhadap Indeks Pembangunan Manusia. 


\section{SIMPULAN}

Penelitian ini menghasilkan simpulan mengenai bagaimana pengaruh pendapatan asli daerah dan belanja modal pada indeks pembangunan manusia di Kabupaten/Kota Provinsi Papua Barat. Terdapat bukti empiris yang diperoleh melalui penelitian ini terkait hasil olah data statistik Kabupaten/Kota di Provinsi Papua Barat tahun 2014-2018 yang menunjukkan pendapatan asli daerah dan belanja modal berpengaruh padaIPM.

Penelitian ini sejalan dengan teori federalism fiscal yang menjelaskan tentang bagaimana hubungan desentralisasi dengan perekonomian, pelayanan publik, dan kesejahteraan kepada masyarakat tercapai dan berpengaruh pada IPM. Penelitian ini diharapkan dapat memberikan kontribusi positif bagi Pemerintah Kabupaten/Kota di Provinsi Papua Barat. Pemerintah daerah hendaknya dapat melakukan pengadaan aset daerah sebagai investasi yang mampu meningkatkan sarana dan prasarana publik sehingga menunjang peningkatan pelayanan sektor publik, karena belanja modal memiliki peran penting terhadap peningkatan IPM.

\section{REFERENSI}

Ashworth, R., G., B., \& Delbridge, R. (2005). Escape from the Iron Cage? Organizational Change and Isomorphic Pressures in the Public Sector. Journal of Public Administration Research and Theory, 1(1), 1- 20.

Azzahra, F., Prihanto, P. H., \& Amzar, Y. V. (2016). Analisis pengaruh belanja modal terhadap Indeks Pembangunan Manusia di Provinsi Jambi. E-Jurnal Ekonomi Sumberdaya Dan Lingkungan, 5(2), 1- 20.

Badrudin, R. (2011). Pengaruh Pendapatan dan Belanja Daerah Terhadap Pembangunan Manusia di Provinsi Daerah Istimewa Yogyakarta. Buletin Ekonom, 9(1), 1- 82.

Barat, B. K. S. P. P. (2019). Pendapatan Asli Daerah Kabupaten/Kota di Provinsi Papua Barat.

Bati. (2009). Pengaruh Belanja Modal Dan Pendapatan Asli Daerah Terhadap Pertumbuhan Ekonomi (Studi Pada Kabupaten Dan Kota Di Sumatera Utara). Universitas Sumatera Utara.

Christy, A., \& Adi, F. (2009). Hubungan Antara Dana Alokasi Umu, Belanja Modal Dan Kualitas Pembangunan Manusia. The 3rd National Conference UKWMS Surabaya.

Darwanto, \& Yustikasari, Y. (2007). Pengaruh Pertumbuhan Ekonomi Pendapatan Asli Daerah dan Dana Alokasi Umum terhadap Pengalokasian Anggaran Belanja Modal. Simposium Nasional Akuntansi X.

Ehimare, O., Barr, E. I., Joshua, O., \& Uchechukwu, E. (2014). The Nigerian Government Expenditure on Human Capital Development : an Efficiency Analysis. European Journal of Business and Social Sciences, 3(7), 1-13.

Handra, H., \& Maryati, S. (2009). Analisis Pendapatan Asli Daerah (PAD) Bukan Pajak Pemerintah Propinsi Sumatra Barat. Konferensi Penelitian Keuangan Sektor Publik II Badan Litbang.

Haryanto, S. (2013). Analisis Pengaruh Pad, Dau Dan Dak Terhadap Belanja Modal Dan Belanja Barang Dan Jasa Kota Dan Kabupaten Di Provinsi Jawa Timur Tahun 2006-2012. Jurnal Ekonomi MODERNISASI, 9(2), 140. 
Holtz-Eakin, D., Harvey, S., \& Tilly, S. (1985). Intempora Analysis of StateA Local Government Spending: Theory and Tests. Journal of Urban Economics, 35(1), $159-174$.

http://www.djpk.kemenkeu.go.id/portal/data/apbd. (2018). APBD. Www.Djpk.Kemenkeu.Go.Id.

Hukom, A. (2015). Effect Of Capital Expenditures, Economic Growth and Poverty on Human Development in Central Kalimantan. IOSR Journal of Economics and Finance, 6(6), 4.

Kresnandra, A. A. N. A. (2016). Pengaruh Desentralisasi Fiskal Terhadap Pertumbuhan Ekonomi Daerah Dengan Dana Perimbangan Dan Investasi Swasta Sebagai Variabel Pemoderasi. Jurnal Bisnis Dan Manajemen, 3(2), 120.

López, J. C., Ruiz, F. J., Feder, J., Barbero-Rubio, A., Suárez-Aguirre, J., Rodríguez, J. A., \& Luciano, C. (2010). The role of experiential avoidance in the performance on a high cognitive demand task. Journal of Psychology and Psychological Therapy, 10, 475-488.

Lugastoro, D. P. (2013). Analisis Pengaruh PAD dan Dana Perimbangan terhadap Indeks Pembangunan Manusia Kabupaten/Kota di Jawa Timur. Jurnal Ilmiah Mahasiswa FEB Universitas Brawijaya, 1(2), 1-20.

Modebe. (2012). Impact of Reccurent and Economic Growth in Pakistan. Bahuddin Zakariya University.

Naganathan, M., \& Sivagnanam, K. J. (2000). Federal Transfers and Tax Efforts of the States in India. Indian Economic Journal, 47(4), 101- 110.

Pamudi, S. B. (2008). Analisis Pengaruh Tingkat Kemandirian Fiskal Terhadap Indeks Pembangunan Manusia Kabupaten/Kota di Provinsi Jawa Barat. Institut Pertanian.

Pradana, M. (2018). Alokasi Belanja Pemerintah dan Indeks Pembangunan Manusia di Indonesia. E-Journal Unitomo, 2(1), 1- 15.

Priambodo, A., \& Noor, I. (2015). Analisis Pengaruh Belanja Pemerintah Daerah Terhadap Indeks Pembangunan Manusia (Studi pada Kabupaten/Kota di Pulau Jawa Tahun 2007-2013). Jurnal Ilmiah Universitas Brawijaya, 3(2), 1- 20.

Sari, I. A. C. Y., \& Supadmi, N. L. (2016). Pengaruh Pendapatan Asli Daerah Dan Belanja Modal Pada Peningkatan Indeks Pembangunan Manusia. E-Jurnal Akuntansi Universitas Udayana, 15(3), 2302.

Sasana, H. (2012). Pengaruh Belanja Pemerintah Daerah Dan Pendapatan Perkapita terhadap Indeks Pembangunan Manusia (Studi Kasus Di Kabupaten/Kota Provinsi Jawatengah). Media Ekonomi Dan Manajemen, 25(1), 1-20.

Setyowati, L., \& Suparwati, Y. K. (2012). Pengaruh Pertumbuhan Ekonomi, Dana Alokasi Umum, Dana Alokasi Khusus dan Pendapatan Asli Daerah terhadap Indeks Pembangunan Manusia dengan Pengalokasian Anggaran Belanja Modal sebagai Variabel Intervening. Prestas, 9(1).

Situngkir, A. (2009). Efek Memiliki Pendapatan Daerah, Pengalokasian Dana Umum, Dan Dana Khusus Pada Belanja Modal Di Kota Dan Kabupaten Sumatera Utara. Kajian Akuntansi, 4(2), 93- 103.

Soejoto, A., Subroto, W. T., \& Suyanto. (2015). Fiscal Decentralization Policy in Promoting Indonesia Human Development. International Journal of Economics 
and Financial, 5(3), 763- 771.

Solikin, I. (2007). Hubungan Pendapatan Asli Daerah dan Dana Alokasi Umum dengan Belanja Modal di Jawa Barat.

Vegirawati, T. (2012). Pengaruh Alokasi Belanja Langsung terhadap Kualitas Pembangunan Manusia (Studi Kasus Pada Pemerintah Kabupaten Kota di Sumatera Selatan). Jurnal Ekonomi Dan Informasi, 2(1), 1- 20.

Yanto, E., R., \& Fattah, V. (2018). Pengaruh Pendapatan Asli Daerah (PAD) dan Belanja Modal Terhadap Indeks Pembangunan Manusia (IPM) (Survei Pada Kabupaten/Kota di Sulawesi Tengah). Jurnal Katalogis, 6(2), 125- 135. 